\title{
Pengaruh Motivasi Kerja Terhadap Kinerja Karyawan Di PT Bess Finance Cabang Bandung
}

\author{
Toto Sugiarto \\ Totosugiartobsr2@gmail.com \\ Program Studi Manajemen, Fakultas Ekonomi, Universitas Al-Ghifari
}

\begin{abstract}
Employees are a valuable corporate asset that must be managed by the company in order to provide optimal contribution. One of the things that should be the primary concern of the company is the job satisfaction of their employees, because the employees in the work they do not feel comfortable, under-appreciated, can not develop all their potential, then automatically the employee unable to focus and concentrate fully on the job. that the motivation to be a very important part of the underlying individual or someone in doing something or achieve the desired purpose.

Salary given to employees company PT Bess Finance so varies according to the position of each. Then the opportunity for career selection to a higher level, reward program for high performing employees. But in certain cases it is also still found a contradictory conditions, which, if observed, would also be potentially lethal even lower motivation.

Based on the background above, the research on the effect of motivation on employee performance in PT Bess Finance, this study takes its object to employees of PT Bess Finance located in Bandung. The independent variable $(X)$ is the motivation to work while the dependent variable $(Y)$ is the performance of the employees. This type of research uses explanatory survey, and the method used is Simple Random Sampling, with a total sample 45 respondents. In addition, research is conducted in a timeframe of less than one year of the study using crosssectional methods. The data used are primary and secondary data and data analysis techniques using statistical parametric application using Spearman rank analysis.

These results indicate that the effect of motivation on employee performance indicates a moderate correlation and significant correlation coefficient of 0.477 . therefore, the suggestion for the Company Bess Finance to pay attention to in terms of work motivation mnghasilkan employees so that they can work effectively and efficiently.
\end{abstract}

Keywords: Work Motivation and Emplovee Performance

\section{Latar Belakang}

Karyawan merupakan aset perusahaan yang sangat berharga yang harus dikelola dengan baik oleh perusahaan agar dapat memberikan kontribusi yang 
optimal. Salah satu hal yang harus menjadi perhatian utama perusahaan adalah kepuasan kerja para karyawannya, karena karyawan yang dalam bekerja mereka tidak merasakan kenyamanan, kurang dihargai, tidak bisa mengembangkan segala potensi yang mereka miliki, maka secara otomatis karyawan tidak dapat fokus dan berkonsentrasi secara penuh terhadap pekerjaannya. Demikian pula sebaliknya, semakin banyak aspek dalam pekerjaannya yang tidak sesuai dengan keinginan dan sistem nilai yang dianut individu, semakin rendah tingkat kepuasan yang didapat. Kepuasan kerja adalah keadaan emosional yang menyenangkan dengan bagaimana para pekerja memandang pekerjaan mereka. Kepuasan kerja mencerminkan perasaan seseorang terhadap pekerjaannya yang dapat terlihat dari sikap karyawan terhadap pekerjaan dan segala sesuatu di lingkungan pekerjaannya. Sebagaimana yang dikemukakan Handoko (1995:196) “ Karyawan yang tidak memperoleh kepuasan kerja tidak akan pernah mencapai kematangan psikologis dan pada gilirannya akan menjadi frustasi."

Aspek-aspek yang dapat membentuk kepuasan kerja karyawan antaralain : faktor individual (umur, jenis kelamin, sikap pribadi terhadap pekerjaan), faktor hubungan antar karyawan (hubungan antar manajer dan karyawan, hubungan sosial antara sesama karyawan, sugesti dari teman sekerja, faktor fisik dan kondisi tempat kerja, emosi dan situasi kerja) faktor eksternal (keadaan keluarga, rekreasi, pendidikan). Aspek tersebut memberikan motivasi agar kepuasan kerja tercapai bagi karyawan. Penulis tertarik pada penelitian ini mebahas tentang apakah motivasi dapat berpengaruh terhadap kinerja karyawan.

Perusahaan juga harus memperhatikan mengenai bagaimana menjaga dan mengelola motivasi pegawai dalam bekerja agar selalu tinggi dan fokus pada tujuan perusahaan. Penilaian atas pelaksanaan pekerjaan yang dilaksanakan karyawan atau sering disebut sebagai penilaian kinerja atau penilaian prestasi kerja juga mutlak dilakukan untuk melihat sampai sejauh mana pemberian motivasi kepada karyawan tersebut. Sistem penilaian kinerja karyawan ini merupakan hasil kerja karyawan dalam lingkup tanggung jawabnya yang tentunya mengacu pada suatu sistem formal dan terstruktur yang digunakan sebagai instrumen untuk mengukur, menilai dan mempengaruhi sifat-sifat yang berkaitan dengan pekerjaan, menngendalikan perilaku karyawan, 
termasuk tingkat ketidak hadiran, hasil kerja, membuat keputusan-keputusan yang berkaitan dengan kenaikan gaji pemberian bonus, promosi dan penempatan karyawan pada posisi yang sesuai.

Menjaga motivasi karyawaan itu sangatlah penting karena motivasi itu adalah motor penggerak bagi setiap individu yang mendasari mereka untuk bertindak dan melakukan sesuatu. Orang tidak akan melakukan sesuatu hal secara optimal apabila tidak mempunyai motivasi yang tinggi dari dalam dirinya sendiri untuk melalukan hal tersebut. Robin dan Judge (2008:222), mendefinisikan motivasi sebagai suatu proses yang menjelaskan intensitas, arah dan ketekunan seorang individu untuk mencapai tujuannya. Dari definisi tersebut dapat dicermati bahwa motivasi menjadi bagian yang sangat penting yang mendasari individu atau seseorang dalam melakukan sesuatu atau mencapai tujuan tertentu yang diinginkan.

Masalah motivasi pada perusahaan haruslah dijadikan sebagai perhatianyang serius dalam Manajemen Sumber Daya Manusianya. Perusahaan-perusahaan modern dewasa ini haruslah menjadikan karyawan sebagai aset, bukan lagi hanya sebagai alat produksi semata. Untuk itu perusahaan perlu menciptakan suatu kondisi yang kondusif yang dapat membuat karyawan merasa nyaman, terpenuhi kebutuhannya, sehingga diharapkan motivasi mereka juga tetap terjaga untuk bersama sama mencapai visi dan misi perusahaan. Kondisi-kondisi kondusif itu bisa bermacammacam, tergantung pada karakteristik perusahaan itu masing masing.

Tapi secara umum diantaranya dapat berupa fasilitas yang disediakan, tingkat kesejahteraan yang memadai, jenjang karir yang jelas, peluang aktualisasi diri, kenyaman dan keamanan dalam bekerja, jaminan hari tua dan lain-lain. Penulis juga tertarik meneliti apakah kepuasan kerja dan motivasi kerja mempunyai pengaruh terhadap kinerja karyawan. Simammora mengungkapkan dalam buku Sumber Daya Manusia (1995:327) kinerja karyawan adalah tingkat terhadap mana para karyawan mencapai persyaratan-persyaratan pekerjaan. Pada PT Bess Finance sebagian dari kondisi-kondisi kondusif dalam menjaga motivasi karyawan itu juga sudah jadi perhatian oleh Divisi Sumber Daya Manusia/HRD nya kemudian dalam hal pemberian gaji karyawan perbulan itu menjadi hal yang paling utama untuk menumbuhkan semangat kerja karyawan. Seperti pada tabel berikut : 
Tabel 1

Daftar Gaji Karyawan Perbulan

\begin{tabular}{|c|c|c|}
\hline No & Jabatan & Gaji/bulan \\
\hline 1 & Branch manager & $4,500,000$ \\
\hline 2 & Credit analyst & $2,000,000$ \\
\hline 3 & Head marketing & $1,800,000$ \\
\hline 4 & Head collection & $2,000,000$ \\
\hline 5 & Head operasional & $2,000,000$ \\
\hline 6 & Ass. Head collection & $2,000,000$ \\
\hline 7 & Ass. Head operasional & $1,800,000$ \\
\hline 8 & Adm kredit & $1,500,000$ \\
\hline 9 & Loan doc & $1,300,000$ \\
\hline 10 & $\mathrm{Hrd} / \mathrm{ga}$ & $1,800,000$ \\
\hline 11 & Uтит & $1,500,000$ \\
\hline 12 & Cust servis & $1,500,000$ \\
\hline 13 & Teller & $1,500,000$ \\
\hline 14 & Cashier & $1,500,000$ \\
\hline 15 & Direct sales & $1,300,000$ \\
\hline 16 & Adm collection & $1,700,000$ \\
\hline 17 & Collector & $1,200,000$ \\
\hline 18 & Ao plus & $1,150,000$ \\
\hline
\end{tabular}

Sumber : Data gaji PT Bess Finance

Gaji yang diberikan perusahaan kepada karyawan PT Bess Finance begitu bervariasi sesuai dengan jabatannya masing-masing. Kemudian kesempatan untuk seleksi karir untuk jenjang yang lebih tinggi, program reward untuk 
karyawan berprestasi. Namun dalam beberapa hal tertentu ternyata juga masih ditemukan kondisi yang kontradiktif, yang bila diamati, juga akan dapat berpotensi menurunkan bahkan mematikan motivasi. Misalnya adanya pembedaan usia pensiun yang lebih dini bagi karyawan frontliners serta penempatan karyawan yang hanya pada posisi/bagian yang sama dalam waktu yang relatif lama. Pada penulisan skripsi ini penulis lebih memfokuskan permasalahan pada kondisi yang dialami oleh karyawan atau karyawati PT Bess Finance Cabang Bandung, apakah karyawan karyawati merasa puas dengan kondisi gedung kantor yang sudah tua, penempatan karyawan pada bagian atau bidang kerja yang sama untuk rentang waktu yang cukup lama, akankah berpengaruh pada kepuasan kerja dan motivasi dari karyawan tersebut dalam bekerja, karena karyawan rentan sekali untuk mengalami kejenuhan akibat pekerjaan monoton yang dijalani. Sampai saat ini masih ada frontliners yang bekerja pada posisi yang sama lebih dari tahun, bahkan dari zaman ekslegasi (masa sebelum PT Bess Finance melakukan merger), mereka telah menjadi frontliners, tanpa pernah dimutasi. Kalaupun ada pelaksanaan mutasi, yang dimutasi hanya tempat bekerja saja tanpa dibarengi mutasi jenis pekerjaannya.

Bekerja pada bidang tugas yang sama untuk waktu yang panjang akan mudah membuat karyawan merasa bosan. Rutinitas kerja yang monoton setiap harinya, pada suatu waktu pasti akan sampai pada titik kejenuhan, yang dapat mengakibatkan karyawan tidak dapat dengan maksimal mengeluarkan kemampuan yang dimiliki untuk kemajuan perusahaan, karena mungkin mereka tidak lagi mempunyai motivasi yang cukup untuk perlu melakukan itu. Karena tahu posisi mereka tidak akan berubah, bisa menyebabkan karyawan tidak lagi punya minat dan kemauan untuk mengembangkan diri, dan pada titik tertentu mungkin saja menjadi tidak perduli dengan produk atau program yang ingin ekspos oleh perusahaan, sebab bagi mereka itu sama sekali tidak akan mempengaruhi posisi dan karir mereka. Kondisi itu bila tidak disikapi dan dikelola dengan baik oleh Manajemen Sumber Daya Manusia di perusahaan, akan dapat menjadi bumerang yang bias merugikan perusahaan. Sebab sebagai ujung tombak, karyawan frontliners sesungguhnya adalah etalase perusahaan di mata konsumen (nasabah). Bagi masyarakat awam, prilaku dan tampilan yang ditunjukkan oleh frontliners 
merupakan representasi dari perusahaan itu dalam pikiran mereka. Oleh sebab itu pengelolaan pada bagian frontliners semestinya dijadikan suatu hal yang strategis oleh semua perusahaan jasa, termasuk oleh PT Bess Finance. Berdasarkan hal-hal tersebut diatas, penulis tertarik untuk membahasnya dalam bentuk penyusunan tugas akhir atau skripsi dengan judul:

"Pengaruh Motivasi Kerja Terhadap Kinerja Karyawan Pada PT. Bess Finance Cabang Bandung".

\section{Kerangka Pemikiran}

Pekerjaan yang dilakukan pada dunia perbankan merupakan salah satu pekerjaan atau aktivitas yang selalu dilakukan secara berulang. Karyawan dihadapkan pada rutinitas yang sama dari hari ke hari. Pada kondisi pekerjaan seperti ini karyawan sangat rentan terhadap kejenuhan yang menyebabkan tidak adanya kepuasan dalam bekerja, selain itu faktor kepuasan financial, kepuasan fisik, kepuasan sosial dan kepuasan psikologi juga berpengaruh terhadap kepuasan kerja. Kurang atau hilangnya motivasi kerja juga berpengaruh terhadap kinerja. Menurut Stephen p. Robbins (2003:208) "motivasi adalah kesedian untuk mengeluarkan tingkat upaya yang tinggi untuk tujuan organisasi, yang di kondisikan oleh kemampuan upaya itu dalam memenuhi beberapa kebutuhan individual".

Karyawan merupakan asset peusahaan yang sangat berharga dan apabila dikelola dengan baik akan menghasilkan keuntungan bagi perusahaan yaitu tercapainya semua tujuan yang telah ditetapkan. Sebagai salah satu Bank yang mempunyai asset terbesar tentu akan amat sangat disayangkan jika PT. Bess Finance tidak dapat mengelola salah satu asetnya yang berharga yaitu karyawan yang dimiliki saat ini dengan baik. PT. Bess Finance harus jeli melihat hal-hal yang bisa menimbulkan kepuasan kerja karyawan, membuat karyawan termotivasi dalam bekerja dan kinerja perusahaan meningkat seiring meningkatnya kinerja karyawan. Oleh sebab itu perlu dikaji dan diteliti apa sesungguhnya yang mempengaruhi hasil kerja atau kinerja karyawan, diantaranya melalui kepuasan kerja karyawan dan motivasi kerja karyawan. Menurut Handoko (1987:135) kinerja adalah ukuran terakhir keberhasilan seorang karyawan dalam melaksanakan pekerjaannya. Pemikiran tersebut digambarkan oleh kerangka kerja teori penelitian seperti berikut: 


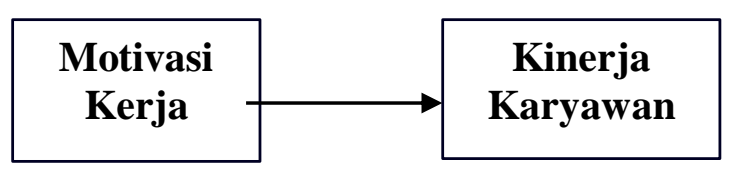

Gambar 1

Kerangka Pemikiran

Pengaruh Kepuasan Kerja dan Motivasi terhadap Kinerja Karyawan

\section{Hipotesis}

Mengacu pada kerangka pemikiran, maka hipotesis yang penulis rumuskan dalam penelitian adalah :

1. Diduga motivasi kerja memiliki pengaruh signifikan terhadap kinerja karyawan pada PT. Bess Finance Cabang Bandung.

2. Diduga motivasi kerja sangat berpengaruh terhadap kinerja karyawan pada PT. Bess Finance Cabang Bandung.

\section{Kajian Teori}

\section{a) Manajemen Sumber Daya Manusia}

Menurut Henry Fayol (dalam stephen p. robbins 2003:5) menyatakan bahwa semua manajer menjalankan empat fungsi manajemen yaitu: perencanaan, pengorganisasian, pemimpinan, dan pengendalian.

1. Perencanaan

Mencangkup penetapan tujuan, penegasan strategi, dan pengembangan rencana untuk mengkoordinasikan kegiatan.

2. Pengorganisasian

Menegaskan apa tugas-tugas yang harus dikerjakan, siapa yang harus mengerjakan, bagaimana tugas-tugas itu dikelompokan, siapa melapor kepada siapa, dan dimana keputusan harus diambil.

3. Pemimpinan

Mencangkup hal memotivasi bawahan, mengarahkan orang lain, menyeleksi saluran-saluran komunikasi yang paling efektif, dan memecahkan konplik-konplik.

4. Pengendalian

Memantau kegiatan-kegiatan untuk memastikan kegiatan itu dicapai sesuai dengan yang direncanakan dan mengkoreksi setiap penyimpangan 
yang berarti. Untuk memastikan bahwa semua urusan berjalan seperti seharusnya, manajemen harus memantau kinerja organisasi. Kinerja yang sebenarnya harus dibandingkan dengan tujuan-tujuan yang ditetapkan sebelumnya.Jika terjadapat penyimpangan yang cukup berarti, adalah tugas manajemen untuk mengembalikan organisasi itu pada jalurnya.

Jadi,dengan menggunakan pendekatan pungsional, jawaban atas pertanyaan apa yang d lakukan para manajer adalah bahwa meraka merencanakan, mengorganisasi, peminpin, dan mengendalikan.

Peranan manajemen menurut Henry Fayol (dalam stephen p. robbins 2003:6) di bagi menjadi tiga kelompok utama yaitu :

1. Peran hubungan antar peribadi adalah semua menejer di tuntut untuk menjalankan tugas-tugas yang sipatnya seremonial dan simbolik. Semua manajer mempunyai peran peminpinan yang mencakup mempekerjakan melatih, memotipasi, dan mendisiplinkan karyawan.

2. Peran informasi adalah sampai tingkat tertentu, semua manajer menerima dan mengumpulkan inpormasi dari organisasi-organisasi dan lembaga-lembaga diluar organisasi mereka sendiri.lajimnya ini di lakukan melalui pembacaan majalah dan berbincang-bincang dengan orang lain untuk mempelajari selera publik, apa yang mungkin yang di rencanakan oleh para pesaing. Para manajer juga bertindak sebagai penyalurn untuk meneruskan inpormasi kepada anggota-anggota organisasi.

3. Peran keputusan adalah dalam peran wiraswasta para manajer memprakasai dan mengawasi proyek-proyek baru yang akan menyempurnakan kinerja organisasi. sebagai penangan terhadap hambatan, manajer mengambil tindakan korektip sebagai tanggapan atas masalah-masalah yang tidak di duga sebelumnya. Para manajer juga menjalankan pada suatu peran perunding mereka membahas berbagai isu dan tawar menawar dengan unit-unit lai untuk memperoleh keuntungn bagi unitnya.

Sumber Daya Manusia (SDM) adalah manusia yang bekerja di lingkungan suatu organisasi (disebut juga personil, tenaga kerja, pekerja atau karyawan). Menurut Mary Parker Follett Manajemen Sumber Daya Manusia 
adalah suatu seni untuk mencapai tujuan-tujuan organisasi melalui pengaturan orang-orang lain untuk melaksanakan berbagai pekerjaan yang diperlukan, atau dengan kata lain tidak melakukan pekerjaan-pekerjaan itu sendiri.

\section{b) Motivasi}

Istilah motivasi, dalam kehidupan sehari-hari memiliki pengertiam yang beragam baik yang berhubungan dengan perilaku individu maupun perilaku organisasi. Namun, apapun pengertiannya motivasi merupakan unsur penting dalam diri manusia, yang berperan mewujudkan keberhasilan dalam usaha atau pekerjaan manusia. Dasar utama pelaksanaan motivasi oleh seorang pimpinan adalah pengetahuan dan pelatihan terhadap perilaku manusia yang dipimpinnya sebagai suatu faktor penentu keberhasilan organisasi.

Menurut Stephen p. Robbins (2003:208) "motivasi adalah kesedian untuk mengeluarkan tingkat upaya yang tinggi untuk tujuan organisasi, yang di kondisikan oleh kemampuan upaya itu dalam memenuhi beberapa kebutuhan individual". Jadi motivasi sebagai satu proses yang menghasilkan suatuinsentisitas, arah, dan ketekunan individual dalam usaha untuk mencapai satu tujuan, sementara motipasi umum bersangkutan dengan upaya kearah setiap tujuan, kami menyempitkan fokus pada tujuan organisasi agar mencerminkan minat tunggal kita dalam prilaku yang berkaitan dengan kerja.

Ketiga unsur kunci dalam definisi motivasi adalah insensitas, tujuan, dan ketekunan. Intensitas menyangkut seberapa kerasnya seseorang berusaha. Ini adalah unsur yang paling difokuskan oleh kebanyakan kita bila kita berbicara tentang motivasi. Akan tetapi, insensitas yang tinggi tidak akan membawa hasil yang diinginkan kecuali kalau upaya itu di arahkan ke suatu tujuan yang menguntungkan organisasi.oleh karna itu, kita harus mempertimbangkan kualitas dari upaya itu maupun intensitasnya. Upaya yang di arahkan menuju, dan konsisten dengan, tujuan-tujuan organisasi adalah upaya yang seharusnya kita usahakan.

Motivasi itu kesedianan untuk mengeluarkan tingkat upaya yang tinggi muntuk tujuan organisasi, yang di kondisikan oleh kemampuan upaya itu dalam memenuhi beberapa kebutuhan individual. Salah satu aspek memanfaatkan pegawai ialah pemberian motivasi (daya perangsang) kepada 
pegawai, dengan istilah populer sekarang pemberian kegairahan bekerja kepada pegawai dengan memanfaatkan pegawai yang memberi manfaat kepada perusahaan. Maksud manfaat disini adalah tercapainya tujuan perusahaan. Ini berarti bahwa setiap pegawai yang memberi kemungkinan bermanfaat ke dalam perusahaan, diusahakan oleh pemimpin agar kemungkinan itu menjadi kenyataan.

Usaha untuk merealisasi kemungkinan tersebut ialah dengan jalan memberikan motivasi, karena motivasi inilah yang menentukan prilaku pegawai untuk bekerja atau dengan kata lain prilaku merupakan cerminan yang sederhana dari motivasi. Motivasi ini dimaksudkan untuk memberikan daya perangsang kepada pegawai yang bersangkutan agar pegawai tersebut bekerja dengan segala daya dan upayanya.Motivasi berasal dari motive atau bahasa latinnya, yaitu movere, yangberarti "mengerahkan". Liang Gie mendefenisikan dalam bukunya Martoyo (1992) motive atau dorongan adalah suatu dorongan yang menjadi pangkal seseorang melakukan sesuatu atau bekerja.

Seseorang yang sangat termotivasi, yaitu orang yang melaksanakan upaya substansial, guna menunjang tujuan-tujuan produksi unit kerjanya, dan organisasi dimana ia bekerja. Seseorang yang tidak termotivasi, hanya memberikan upaya minimum dalam hal bekerja. Dengan demikian dapat dikatakan bahwa motivasi pada dasarnya adalah kondisi mental yang mendorong dilakukannya suatu tindakan (action atau activities) dan memberikan kekuatan yang mengarah kepada pencapaian kebutuhan, memberi kepuasan ataupun mengurangi ketidak seimbangan.memberi manfaat kepada perusahaan.

Berbagai hal yang terkandung dalam definisi motivasi menurut Siagian (1995:142) memiliki tiga komponen utama, yaitu:

1. Kebutuhan.

Kebutuhan timbul dalam diri seseorang apabila orang tersebut merasa ada kekurangan dari dalam dirinya. Menurut pengertian homeostatic, kebutuhan timbul atau diciptakan apabila dirasakan adanya ketidakseimbangan antara apa yang dimiliki, baik dalam arti fisikologis maupun psikologis.

2. Dorongan. 
Usaha untuk mengatasi

ketidakseimbangan biasanya menimbulkan dorongan. Hal tersebut merupakan usaha pemenuhan kekurangan secara terarah yang berorientasi pada tindakan tertentu yang secara sadar dilakukan oleh seseorang yang dapat bersumber dari dalam maupun dari luar diri orang tersebut.

3. Tujuan

Tujuan adalah segala sesuatu yang menghilangkan kebutuhan dan mengurangi dorongan. Mencapai tujuan, berarti mengembalikan keseimbangan dalam diri seseorang, baik bersifat fisiologis maupun bersifat psikologis. Tercapainya tujuan akan mengurangi atau bahkan menghilangkan dorongan tertentu untuk berbuat sesuatu.

Beberapa pengertian motivasi yang dikemukakan oleh para ahli tersebut dapat dinyatakan bahwa motivasi kerja terbentuk dari adanya kebutuhan, sikap (attitude) yang mendorong karyawan agar lebih bersemangat dan bergairah dalam menghadapi situasi kerja diperusahaan. Motivasi kerja merupakan kondisi atau energy yang menggerakkan diri karyawan yang terarah atau tertuju untuk mencapai tujuan organisasi perusahaan.

\section{c) Kinerja Karyawan}

Pada dasarnya kinerja seorang karyawan merupakan hal yang bersifat individual karena setiap karyawan mempunyai tingkat kemampuan yang berbeda-beda dalam mengerjakan tugas pekerjaannya. Kinerja seseorang bergantung pada kombinasi dari kemampuan, usaha dan kesempatan yang diperoleh. Menurut Handoko (1987:135) kinerja adalah ukuran terakhir keberhasilan seorang karyawan dalam melaksanakan pekerjaannya. Dari pendapat diatas dapat disimpulkan bahwa kinerja adalah kemampuan karyawan dalam mencapai kerja yang dapat dipertanggungjawabkan.

Kinerja sangat penting untuk mencapai tujuan dan akan mendorong sesorang untuk lebih baik lagi dalam pencapaian tujuan. Untuk mengukur tingkat kinerja karyawan biasanya menggunakan performance system yang dikembangkan melalui pengamatan yang dilakukan oleh atasan dari masingmasing unit kerja dengan beberapa alternatif cara penilaian maupun dengan 
cara wawancara langsung dengan karyawan yang bersangkutan. Informasi yang diperoleh dari penilaian kinerja tersebut dapat digunakan bagi penyelia atau manajer untuk mengelola kinerja karyawan, mengetahui apa penyebab kelemahan maupun keberhasilan dari kinerja karyawan sehingga dapat dipergunakan sebagai pertimbangan untuk menentukan target maupun langkah perbaikan selanjutnya dalam mencapai tujuan badan usaha.

Kinerja (performence) di pengaruhi oleh tiga factor sebagai berikut:

1. Faktor individual yang terdiri dari kemampuan dan keahlian, latar belakang, dan demografi.

2. Factor psikologis yang terdiri dari persepsi, attitude (sikap), personality (kepribadian), pembelajaran, dan motivasi.

3. Faktor organisasi yang terdiri dari sumber daya, kepemimpinan, penghargaan, struktur, dan job design (Mankunegara, 2005:14).

\section{Metode Penelitian}

Berdasarkan tingkat dan bidang penelitian, maka jenis penelitian ini bersifat deskriptif dan verifikatif. Menurut Sugiyono (2008:29), penelitian deskriptif adalah penelitian yang berfungsi untuk mendeskripsikan atau memberi gambaran terhadap objek yang diteliti melalui data sampel atau populasi sebagaimana adanya, tanpa melakukan analisis dan membuat kesimpulan yang berlaku untuk umum. Penelitian deskriptif dilakukan untuk memperoleh gambaran mengenai kompensasi terhadap kepuasan kerja karyawan, sedangkan sifat penelitian verifikatif menurut Suharsimi Arikunto (2006:8) pada dasarnya ingin menguji kebenaran dari suatu hipotesis yang dilaksanakan melalui pengumpulan data di lapangan.

Berdasarkan jenis penelitiannya yaitu penelitian deskriptif dan verifikatif maka metode yang digunakan dalam penelitian ini adalah explanatory survey. Explanatory Survey adalah suatu survei yang digunakan untuk menjelaskan hubungan kausal antara dua variabel melalui pengujian hipotesis, survei dilakukan dengan cara mengambil sampel dari satu populasi dan menggunakan kuesioner sebagai alat pengumpul data. Menurut Kerlinger yang dikutip oleh Sugiyono (2008:7), yang dimaksud dengan metode survei yaitu Metode penelitian yang dilakukan pada populasi besar maupun kecil, tetapi data yang dipelajari adalah data dari sampel yang diambil dari populasi 
tersebut, sehingga ditemukan kejadian-kejadian relatif, distribusi, dan hubungan-hubungan antar variabel sosiologis maupun psikologis.

Pada penelitian yang menggunakan metode ini informasi dari sebagian populasi dikumpulkan langsung di tempat kejadian secara empirik dengan tujuan untuk mengetahui pendapat dari sebagian populasi terhadap objek yang sedang diteliti. Berdasarkan kurun waktu penelitian, metode yang digunakan dalam penelitian ini adalah cross sectional method, karena penelitian ini dilaksanakan dalam kurun waktu yang tidak berkesinambungan dan panjang. Husein Umar (2003:45) mengemukakan bahwa cross sectional method adalah metode penelitian dengan cara mempelajari objek dalam satu kurun waktu tertentu, tidak berkesinambungan dalam waktu panjang. Sementara itu menurut Malhotra (2005:95), cross sectional method adalah jenis rancangan riset yang terdiri dari pengumpulan informasi mengenai sampel tertentu dari elemen populasi hanya satu kali.

Sugiyono (2008:72) mengemukakan definisi populasi, yaitu sebagai Wilayah generalisasi yang terdiri atas: objek atau subjek yang mempunyai kualitas dan karakteristik tertentu yang ditetapkan oleh peneliti untuk dipelajari dan kemudian ditarik kesimpulannya. Populasi bukan hanya sekedar orang, tetapi juga benda-benda alam yang lainnya. Populasi juga bukan sekedar jumlah yang ada pada objek atau subjek itu, tetapi meliputi seluruh karakteristik/sifat yang dimiliki objek atau subjek itu.

Penentuan populasi harus dimulai dengan penentuan yang jelas mengenai populasi yang menjadi sasaran penelitiannya yang disebut populasi sasaran yaitu populasi yang akan menjadi cakupan kesimpulan penelitian. Jadi apabila dalam sebuah hasil penelitian dikeluarkan kesimpulan, maka menurut etika penelitian kesimpulan tersebut hanya berlaku untuk populasi sasaran yang telah ditentukan. Populasi yang akan diambil dalam penelitian ini adalah karyawan PT Bess Finance Cabang Bandung dengan jumlah karyawan PT Bess Finance Sebanyak 76 orang, data tersebut diperoleh dari karyawan PT Bess Finance.

Sampel adalah bagian dari populasi yang akan dijadikan bahan penelitian. Menurut Sugiyono, bahwa yang dimaksud dengan sampel adalah sebagian dari jumlah dan karakteristik yang dimiliki oleh populasi tersebut 
(2008:116). Bila populasi besar, dan peneliti tidak mungkin mempelajari semua populasi yang ada (karena keterbatasan dana, waktu dan tenaga), maka peneliti dapat menggunakan sampel yang diambil dari populasi itu. Apa yang dipelajari dari populasi itu, kesimpulannya akan diberlakukan untuk populasi.

Untuk menentukan sampel dari populasi yang telah ditetapkan, perlu dilakukan suatu pengukuran yang dapat menghasilkan jumlah n. Husain Umar (2003:59), mengemukakan bahwa ukuran sampel dari suatu populasi dapat menggunakan bermacam-macam cara, salah satunya adalah dengan menggunakan teknik slovin dengan rumus:

$$
n=\frac{N}{1+N e^{2}}
$$

Keterangan:

$\mathrm{n}=$ Ukuran sampel

$\mathrm{N}=$ Ukuran populasi

$\mathrm{e}=$ presentase kelonggaran ketelitian karena kesalahan pengambilan sampel yang maíz dapat ditolelir $(\mathrm{e}=0,15)$

$$
\begin{aligned}
& n=\frac{76}{1+76(0.1)^{2}} \\
& n=43,18
\end{aligned}
$$

\section{Hasil Penelitian}

Berdasarkan perhitungan statistik yang didasarkan pada angka-angka dari masing-masing variabel, terlebih dahulu dilakukan transformasi, dimana dalam perhitungan transformasi dilakukan dengan program yang ada dalam SPSS Versi 13.0. hasil korelasi antara variabel motivasi terhadap kinerja karyawan dapat dilihat pada Tabel 4.30 sebagai berikut:

Tabel 2

Matriks Korelasi Antara Motivasi terhadap Kinerja Karyawan

\begin{tabular}{|c|c|c|}
\hline & $\begin{array}{c}\text { Kinerja } \\
\text { Karyawan }(\mathbf{Y})\end{array}$ & Motivasi (X) \\
\hline $\begin{array}{c}\text { Kinerja } \\
\text { Karyawan (Y) }\end{array}$ & $\mathbf{1 . 0 0 0}$ & $\mathbf{. 6 5 2}$ \\
\hline Motivasi (X) & $\mathbf{. 6 5 2}$ & $\mathbf{1 . 0 0 0}$ \\
\hline
\end{tabular}


Sumber : Hasil pengolahan data

Pada Tabel 2 menunjukan bahwa adanya hubungan setiap variabel $\mathrm{X}$ dan Y serta hubungan antara variabel independent. Berdasarkan tabel 4. dapat dilihat bahwa hubungan variabel Motivasi (X) dengan kinerja karyawan (Y) yaitu sebesar 0.652, jadi dapat disimpulkan bahwa koefisien korelasi variabel motivasi dengan kinerja karyawan terdapat hubungan yang kuat.

Uji hipotesis secara keseluruhan melalui uji $\mathrm{F}$ dengan bantuan program SPSS 13,0. Ho ditolak jika $F_{\text {hitung }}>F_{\text {tabel, }}$ artinya kinerja karyawan dipengaruhi oleh motivasi. Ho diterima jika $F_{\text {hitung }}<\mathrm{F}_{\text {tabel, }}$, artinya kinerja karyawan dipengaruhi oleh motivasi. secara simultan maupun parsial. Pengujian secara keseluruhan secara manual dilakukan dengan rumus sebagai berikut:

$$
F=\frac{(n-k-1) R_{Y X_{k}}^{2}}{k\left(1-R_{Y X_{k}}^{2}\right)}=\frac{(45-2-1)((0,478)}{2(1-0,478)}=19.23
$$

Berdasarkan perhitungan diatas bahwa nilai $F_{h i t u n g}>F_{\text {tabel }}$ adalah 19.23 > dan pada output komputasi program SPSS 13,0 adalah ditunjukkan oleh tabel anova yang menyajikan nilai $\mathrm{F}$ dengan nilai $\mathrm{P}=0,000$, karena nilai $\mathrm{P}<0,05$. Karena $F_{\text {hitung }}>F_{\text {tabel }}$ maka keputusannya adalah $\mathrm{H} 0$ ditolak sehingga dapat diambil kesimpulan $\mathrm{H} 0$ ditolak maka secara keseluruhan pengujian dapat dilakukan. Tabel 4.31yang menunjukan hasil $\mathrm{F}$ hitung dengan tabel anova sebagai berikut:

\section{Tabel 3}

ANOVAb

\begin{tabular}{|c|c|c|c|c|c|c|}
\hline Mode & & $\begin{array}{l}\text { Sum of } \\
\text { Squares }\end{array}$ & df & Mean Square & $\mathrm{F}$ & Sig. \\
\hline \multirow[t]{3}{*}{1} & Regression & 191.227 & 2 & 95.613 & 19.235 & $.000^{\mathrm{a}}$ \\
\hline & Residual & 208.773 & 42 & 4.971 & & \\
\hline & Total & 400.000 & 44 & & & \\
\hline
\end{tabular}

a. Predictors: (Constant), $\times 2, \times 1$

b. Dependent Variable: $y$

Berdasarkan hasil uji hipotesis mengenai motivasi terhadap kinerja karyawan diperoleh nilai signifikansi lebih kecil jika dibandingkan dengan 0.05 berarti Ho ditolak. Pengujian hipotesis juga dapat dilakukan dengan 
membandingkan uji $t_{\text {tabel }}$ dengan $t_{\text {hitung }}$ dengan $\alpha=0.05$. Perhitungan data setiap variabel menghasilkan $t_{\text {hitung }}$ lebih besar dari $t_{\text {tabel }} 1.984$ sehingga menyatakan bahwa Ho ditolak.

Berdasarkan tabel pengaruh terbesar diberikan motivasi dengan memberikan pengaruh langsung terhadap kinerja karyawan sebesar 0.250 total pengaruh yang diberikan oleh distribusi terhadap keputusan pembelian sebesar 0,325 atau 32,5\% Struktur kausal antara kualitas produk, distribusi dan keputusan pembelian dapat dilihat pada Gambar 2 sebagai berikut:

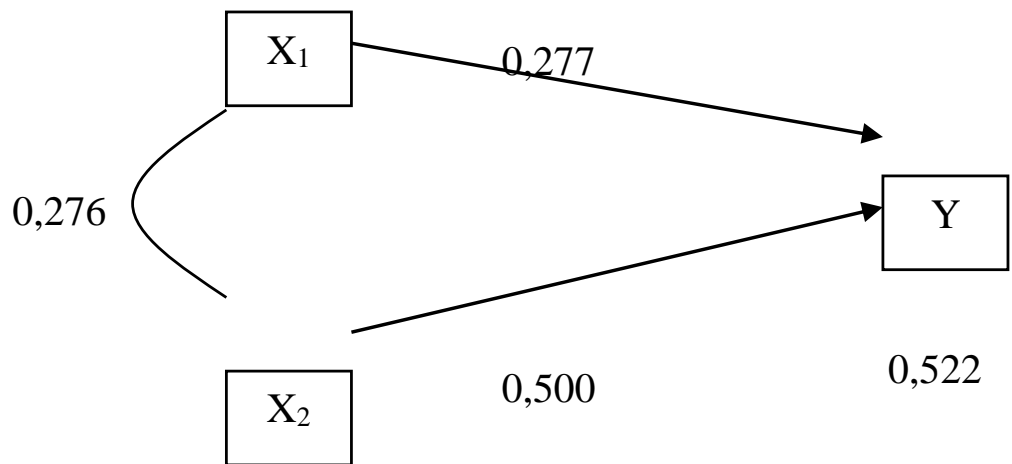

Gambar 2

Diagram Jalur Hipotesis

Berdasarkan perhitungan pengujian hipotesis diketahui secara bersamasama pengaruh kualitas produk, distribusi dan keputusan pembelian sebesar 0,478 atau $47,8 \%$. Hal ini menunjukkan ada pengaruh yang kuat dan signifikan antara kualitas produk, distribusi dan keputusan pembelian ditentukan melalui rumus:

$$
\begin{aligned}
\mathrm{P}_{\mathrm{Y} \varepsilon} & =\sqrt{1-\mathrm{R}^{2} \mathrm{Y}_{(\mathrm{X} 1 \mathrm{X} 2)}} \\
P_{Y \varepsilon} & =\sqrt{1-0.478} \\
P_{Y \varepsilon} & =\sqrt{0.522}=0.722
\end{aligned}
$$

Kualitas produk dan distribusi bersama-sama mempengaruhi keputusan pembelian sebesar 47,8\% dan sisanya sebesar 52,2\% dipengaruhi faktor lain yang tidak termasuk ke dalam penelitian. Istilah motivasi, dalam kehidupan sehari-hari memiliki pengertiam yang beragam baik yang berhubungan 
dengan perilaku individu maupun perilaku organisasi. Namun, apapun pengertiannya motivasi merupakan unsur penting dalam diri manusia, yang berperan mewujudkan keberhasilan dalam usaha atau pekerjaan manusia. Dasar utama pelaksanaan motivasi oleh seorang pimpinan adalah pengetahuan dan pelatihan terhadap perilaku manusia yang dipimpinnya sebagai suatu factor penentu keberhasilan organisasi.

Menurut Stephen p. Robbins(2003:208) "motivasi adalah kesedian untuk mengeluarkan tingkat upaya yang tinggi untuk tujuan organisasi, yang di kondisikan oleh kemampuan upaya itu dalam memenuhi beberapa kebutuhan individual". Berdasarkan pengolahan data sebelunya tetang motivasi bahwa skor tertinggi 1032 atau 65,52\% menyatakan motivasi yang dilakukan di PT Bess Finance berada pada kurang baik, jadi motivasi kerja yang dilakukan oleh PT Bess Finance masih kurang baik yaitu pada indikator kenyamanan tempat, kurang nyamannya tempat yang diberikan PT Bess Finance.

Perusahaan perlu membuat motivasi kerja yang mampu memenuhi kebutuhan karyawan sehingga karyawan merasa aman dan yaman baik dari upah yang di berikan maupun situasi kerjanya, yaitu dengan menyesuaikan lagi antara gaji yang diberikan dengan kinerja karyawan. Pada dasarnya kinerja seorang karyawan merupakan hal yang bersifat individual karena setiap karyawan mempunyai tingkat kemampuan yang berbeda-beda dalam mengerjakan tugas pekerjaannya. Kinerja seseorang bergantung pada kombinasi dari kemampuan, usaha dan kesempatan yang diperoleh. Menurut Handoko (1987:135) kinerja adalah ukuran terakhir keberhasilan seorang karyawan dalam melaksanakan pekerjaannya.

Menurut Hersey and Blanchard, kinerja adalah suatu pungsi dari motivasi dan kemampuan. Untuk menyelesaikan tugas atau pekerjaan, seseorang harus memiliki derajat kesediaan dan tingkat kemampuan tertentu. Kesediaan dan keterampilan seseorang tidaklah cukup efektif untuk mengerjakan sesuatu tanpa pemahaman yang jelas tentang apa yang akan dikerjakan dan bagaimana mengerjakannya. Jadi jika kinerja karyawan baik akan menghasilkan pekerjaan yang efektif dan efisien sehingga dapat membantu pertumbuhan perusahaan.

Berdasarkan hasil pengolahan data, untuk pengaruh variabel motivasi dilakukan pengujian hipotesis dengan membandingkan $t_{\text {tabel }}$ dengan $t_{\text {hitung }}$, 
untuk $\alpha=0,05$ maka nilai tabel adalah 1,984 . Hasil pengolahan data menunjukkan nilai $t_{\text {hitung }}$ sebesar 3,750 sehingga $t_{\text {hitung }}>t_{\text {tabel }}$, maka Ho ditolak dan memperlihatkan hubungan yang positif. Adanya hubungan positif antara motivasi terhadap kinerja karyawan.

Hasil pengujian hipotesis menunjukan bahwa motivasi mempengaruhi kinerja karyawan sebesar 47,8\% dan sisanya sebesar 52,2\% dipengaruhi oleh faktor lainnya yang tidak termasuk pada penelitian ini. maka kinerja karyawan akan meningkat 47,8\% dan selebihnya dipengaruhi oleh faktor lainnya misalnya kepuasan kerja sebesar 52,2\%.

Berdasarkan pendapat diatas jadi perusahaan akan melakukan perbaikan dalam hal motivasi kerja karyawan sehingga karyawan merasa nyaman bekerja di PT Bess Finance.

\section{Kesimpulan}

Berdasarkan hasil penelitian mengenai pengaruh motivasi terhadap kinerja karyawan dapat disimpulkan sebagai berikut:

1. Gambaran motivasi berdasarkan tanggapan responden memiliki kinerja yang tergolong rendah tetapi mendekati tinggi. skor tertinggi 1032 atau 65,52\% menyatakan motivasi yang dilakukan oleh PT Bess Finance berada pada kurang baik, skor yang rendah harus di perbaiki pada kenyamanan suasana kerja yang diberikan oleh PT Bess Finance, dengan cara diberikan fasilitas lain seperti internet yang online, dan gaji yang sepadan dengan pekerjaannya.

2. Gambaran kinerja karyawan berdasarkan tanggapan responden berada dalam tinggi. tanggapan respoden mengenai faktor-faktor kinerja terdiri dari factor internal dan factor eksternal. Factor internal (disposisional), yaitu factor yang dihubungkan dengan sifat-sifat seseorang. Factor eksternal, yaitu factor-faktor yang mempengaruhi kinerja seseorang yang berasal dari lingkungan, seperti perilaku, sikap, dan tidakan-tindakan rekan kerja, bawahan atau pimpinan, fasilitas kerja, dan iklim organisasi. Faktor-faktor internal ini merupakan jenis-jenis atribusi yang mempengaruhi kinerja seseorang berada pada kategori tinggi. Bahwa secara umum sebagian besar karyawan yang sudah lama bekerja di PT Bess Finance. 
3. Secara keseluruhan berdasarkan hasil pengujian menujukan motivasi berpengaruh signifikan pada Kinerja karyawan PT Bess Finance. Motivasi mempengaruhi kinerja karyawan yaitu perbandingan motivasi yang berpengaruh lebih besar pada kinerja karyawan.

\section{Daftar Pustaka}

Arikunto Suharsimi. (2006). Perosedur Penelitian. Jakarta: Rineka CIpta

Desler, Gark, 1999. Manajemen Personalia (Terjemahan Moh, Masud). Jakarta, Erlangg

Edwin B. 1987. ManajemenPersonalia (Terjemahan Moh Masud) Edisi Ke IV, Jakarta Erlangga.

Hany, T. Handoko. 1994. Manajemen Personalia Dan Sumber Daya Manusia, Yogyakarta BFEFillipo,

H. John \& Joyce, E. Arussel, (1993). Human Resource management: an experiental approanchs. Singapore:MC. Graw hill internasional

john. 1988. Penelitian Pelaksanaan Pekerjaandan Pengembangan Karyawan, Yogyakarta: BPFE UGM. Bernardin,

Kusendi Dan Edi Suryadi,(2005). Panduan Oprasional Metode Penelitian Ilmiah, Bandung: UPI

Sugiyono. (2008). Metode Penelitian Bisnis. Bandung: alfabeta,

Sugiyono. (2008). Statistika Untuk Penelitian. Bandung: Alfabeta,

Robbins Stephen P. (2003). Prilaku Organisasi. PT Indeks Kelompok Gramedia

Sopian Pian. (2008). Hubungan Atribut Produk Dengan Loyalitasd Pelanggan. Bandung: Skripsi UPI

Sugiono. (2008). Metode Penelitian Bisnis. Bandung: alfabeta

Sugiyono. 2007. Statistika Untuk Penelitian. Bandung: Alfabeta, 